\title{
Research on the Liability of School Sports Injury Accident under the Comparative
}

\author{
Fangqing $\mathrm{Yu}^{1, \mathrm{a}^{*}}$ and Huixiong $\mathrm{HaO}^{2, \mathrm{~b}}$ \\ ${ }^{1}$ School of Physical Education, Yulin University Yulin Shaanxi, China \\ ${ }^{2}$ Yu Lin No 4 Middle School Yulin Shaanxi, China \\ a594541960@qq.com, b562943759@qq.com
}

Keywords: Comparative perspective; School sports Shanghai accident; Imputation

\begin{abstract}
For students, the school will often take part in some sports events, this time if there is an injury accident, how to identify the responsibility? To solve this problem, this paper through the contrast in the last five years and five years before the injury accident in school physical education return to duty case, from a legal point of view to explore the inquiry of school liability and student the responsibility, clear responsibility schools, teachers, parents, students in sports injury accident should bear, expectating can effectively avoid the occurrence of accidents, even in the event of an accident, also can the rights according to the law.
\end{abstract}

\section{Study the School Sports Injury Accident Liability in the Last Five Years}

Identify School Responsibility. Students enter the school to receive education, so between the two with education relationship, according to the provisions of China's relevant legal provisions, school for students must do the duty of education, management, supervision and protection obligations, if not to fulfill the obligations, then it must be bear corresponding civil liability. For sports injury accidents in school, the school's responsibility is identified, including two cases, one is the school to assume full responsibility, one is the school only need to bear part of the responsibility.

School Bear Full Responsibility. For school bearing full responsibility, generally speaking school in teaching venues and facilities, all aspects of food safety and teaching management because of the negligence ,and cause damage, then it must be bear full responsibility, and this is the ultimate responsibility. China promulgated the "student injury accident treatment approach" in the ninth clearly defined the school should take full responsibility for the eleven cases. In addition, again according to the tort liability law of Article 38 stipulates, said for without person of civil action competence by injury, schools have the burden of responsibility, if the school is not able to adduce evidence to say that his innocence, then it must bear full responsibility.

For example, May 23, 2013. The in physical education classes in a junior high school for training on parallel bars, a junior student from the parallel bars fall down, immediately rushed and went the hospital for treatment, after examination was diagnosed as a fracture. In hospitalized 15 days after discharge. The court for the accident cause of investigation, found that because of screw loosening caused by parallel bars. The school's parallel bars have are used for a long time and is exposed to the wind and rain, screws have been gradually corrosion, becoming aging, so there is a certain security risks. Schools must do their best to education, management, supervision, protection of the obligation, because of the school's negligence and the students were injured, so the need to assume full responsibility. If an accident occurs to the students who are without civil capacity, that is, less than 10 years of age, and the school cannot prove that they are not at fault, then it should bear all the responsibility.

Schools Bear Part of the Responsibility. On the part of the responsibility, the school is only in accordance with the size of their own fault to determine the proportion of responsibility. To bear part of the responsibility is divided into two kinds, respectively, according to the responsibility and the corresponding supplementary liability. In the introduction of the "personal injury compensation interpretation" of the seventh and the "tort liability act" of the sixth, are for the responsibility of the 
relevant provisions. In school sports injury accident is not all by the school's fault, then the school does not need to assume full responsibility, only need to bear part of the responsibility.

For example, on 2 June 2014, physical education classes in a junior high school, student Wang and Zhang because soccer and dispute, sports teacher Li timely adjusted, but when Li after leaving a, Wang and Zhang contradictions upgraded. And then fighter, resulting in Wang leg fracture, Wang was admitted to the hospital for treatment. In this case, Wang and Zhang are students, Zhang was educated in schools, schools did not care obligations, so "tort liability act" in accordance with the provisions of Article 32, Zhang's guardians need bear no fault of vicarious liability. Schools for students with the obligation of education, management, protection, the teacher Li although timely adjusted, but there is no real harm to avoid the occurrence, so Lee also had fault. In accordance with the relevant provisions of the tort liability law, the relevant provisions of the thirty-fourth, if the teacher is at fault, then do not need to bear the responsibility, also do not need to bear joint and several liability, the responsibility needs to be borne by the school. Therefore, in this case should be borne by Zhang's guardian and school responsibility, schools need to assume responsibility for the. After school, the teacher may be asked Lee to recover.

In addition, in the "tort liability act" Article 40 is the school should bear the supplementary liability provisions, the provisions of the "no civil capacity or a person with limited capacity for civil conduct in the kindergarten, school or other educational institution during the period of studying or living, by young kindergartens, schools or other institutions of education outside the staff personal injury, the tortfeasor assume tort liability; the kindergarten, school or other educational institution fails to fulfill its management duties, bear the corresponding supplementary liability."

School does not Take Responsibility. According to the "student injury accident treatment method" and "tort liability law" in the relevant provisions can be clear, the following four kinds of schools do not need to assume responsibility:

Firstly, for the occurrence of sports injury accident, schools have no fault, or that schools can prove that he has all the education, management and protection obligations, then for the occurrence of sports injury accident schools are not required to assume responsibility;

Secondly, although the sports injury accident occurred in the school, but the root cause of the accident is not in school, but by third people outside the school, but the school is not at fault, then the school does not need to assume responsibility;

Thirdly, education and thought of schools and school staff appropriate, but in the school, students have suicide, self-injurious behavior, the schools also don't need to assume responsibility;

Fourthly, the school's teaching and administrative staff in the implementation of the students caused by the damage to the students by the teachers themselves, the school does not need to assume responsibility.

Student Responsibility Cognizance. Between the student and the student is different, according to the relevant provisions of the general principles of civil law, in our country what can be found that adults have reached the age of 18 , is a person with full capacity for civil conduct, so you can assume responsibility for their own civil; not yet reached the age of 18 years of age is minor, belonging to without civil capacity or limited capacity for civil conduct, civil liability need to be borne by the legal guardian. Therefore, the adult students themselves bear the responsibility, the responsibility of the guardian of the minor students.

In the injury accidents of students approach, "the provisions of Article 6" students should obey the school rules and regulations and discipline; in different educational stages shall according to their age, cognitive capacity and legal capacity of, avoid and eliminate the corresponding risk. "For minor students, if their guardians in the process of their injuries are not doing their duty of care, then the need to assume responsibility. So in the school sports injury accident, if the students themselves are at fault, they should bear the responsibility; if students and schools are not at fault, then you need to according to the principle of equitable liability, the two sides together to undertake the responsibility. 


\section{A Comparative Study on the Responsibility of Sports Injury Accidents in the Last Five Years}

Establish the Type of Guardianship Duties to the Independent Responsibility to. In the past, the legal relationship between schools and students is not clear, even some parents think school for students with the duty of guardianship, and even some of the judges will also from this point of view, the introduction of the law did not clearly define the relationship between the students and the school. With the progress of the times, people's ideas are constantly changing, the legal relationship between students and schools has become more clear, more prominent in the school education management responsibilities. According to the 2002 introduction of the "student injure accident treatment measures" and in 2003 issued interpretation on Several Issues concerning the application of law in the trial of personal injury compensation case, have made it clear that school for minor students and does not care obligations, only education, management and protection obligations. But this is only the department regulations and judicial interpretation, and there are no clear legal provisions. In 2010, the National People's Congress passed the "tort liability act", which Article 2 and Article 5 of the types of tort liability to the authority for the arbitrary provisions, Article 32, 38, 39, 40 of respectively, under the liability of guardian, nursery schools or other institutions of education civil tort liability, the third party infringement school supplementary liability, so as to establish the type of independent responsibility in student injury accidents.

Transition by the Fault Principle, the Principle of Fairness to the Presumption of Fault Liability. In the past, according to the school sports injury accident, in processing time, following the principle of fault principle and the fairness principle, the main or fault principle, the principle of fairness is to a secondary role. In accordance with the "tort liability act" in the provisions of Article 38 of can be found, as without person of civil action competence of the students, if the accident occurred in the school itself by some damage, so the school must bear the burden of proof. That is to say, for the students of the injury accident, first found that the school has a certain fault, so they need to assume legal responsibility. But if schools want to say there is no fault of their own, they do not need to undertake the legal liability, then they need to provide relevant evidence to prove that he is not at fault, and there is no need to assume responsibility, if you cannot find the relevant evidence, then it can only bear the responsibility. Sports injury accidents are part of the injury accident, so it is also applicable to this principle. For students who have no capacity for civil conduct, the liability of sports injury accidents should be followed by the principle of fault presumption, and the students who have limited capacity for civil conduct should follow the principle of fault liability. The emergence of the principle of presumption of fault, making the school in the actual judicial process is difficult to win, to improve the liability of compensation.

To Strengthen the Education, Management and Protection of Minors. As cases were described occurred in schools for sports accidents, if the school is at fault, so that students get hurt, the school need to; If the teacher is at fault, so that students are hurt, then the school needs to take responsibility; During the period of school, the students from the non-school third party damage, if the school or the teacher did not do their duties, then it should bear the corresponding responsibility. Even because of the unexpected accidents that occur between students and students, such as playing basketballs which is not caused by the school's behavior, then the two sides do not need to assume fault liability. But will take into account the fair principle, by the school and the injured students to give serious injuries to students of a certain economic compensation.

\section{Schools Establish and Improve Safety Regulations}

First, develop safety management regulations. No rules, no standards, want to reduce the chance of school sports injury, it is necessary to develop practical safety regulations. Safety regulations enacted to meet the actual situation, the implementation of higher. Conduct supervision and management of the implementation of the situation at any time.

Secondly, it should establish the emergency treatment center of sports injury accident. For students in sports injury accident damage, in many cases, if it can be processed in a timely manner, then it will reduce the degree of injury, so the school should establish a sports injury accident 
emergency treatment center. The center should be an emergency treatment for victims of sports injuries; school should be kept a good scene, to facilitate the judiciary to collect evidence; should promptly contact the parents, the parents of a clear reason. In addition, it should also regularly carry out safety education, improve teachers and students of the security concept, and to the teachers and students to help themselves.

Once again, should establish the system of sports insurance regulations. At the present stage, our country existing school sports insurance, but only "learning the insurance" and "school liability insurance, the two sports insurance can play a complementary role, but I have to say, both also has some defects. "Insurance" very easily influenced by the social influence of medical insurance, so in of compensation will meet all kinds of disputes; the school liability insurance is limited in scope, just in primary and secondary schools for, in Colleges and universities is not suitable. The establishment of sports insurance regulatory system, in addition to the two major types of insurance, but also should build a variety of additional risks, as an auxiliary.

Finally, should strengthen the management of sports equipment and sports equipment. Most of the school's sports equipment are located in the stadium, are often subjected to wind and rain, and so very easily subjected to corrosion, aging, resulting in potential safety problems. Schools should carry out regular inspections and maintenance of this equipment, if you encounter more severe weather, but also should be on the sports site inventory, if necessary, should also set a warning signs to remind.

Strengthen Teachers and Students' Awareness of Safety Precautions. If want to avoid the occurrence of sports injury accidents, it is necessary to strengthen the awareness of teachers and students' safety awareness. Firstly, schools should start work on the safety education, is not only for students, should also for teachers, so the two are able to learn to the relevant legal provisions, especially teachers, should also study the safety measures. Secondly, the PE teachers should follow professional ethics, improve accountability, strengthen communication between students, to understand each student's interests, to address differences between students and between students and avoid sports injuries as a result of individual differences. Finally, teachers should set an example to guide students to pay attention to safety in physical education, to have a sense of security, to be disciplined, thereby reducing unnecessary sports injuries.

\section{References}

[1] Liu Naibao, Yan Feng, Yang Ming. Study on the responsibility attribution and security mechanism of school sports injury accidents [J].Sports and science, 2015, 01:91-95+101.

[2] Zhou Jianhua. Study on the imputation of injury accident in school physical education under the comparative perspective [J].Journal of Hunan Institute of Engineering (SOCIAL SCIENCE EDITION), 2015, 02: 121-126.

[3] Zhuangjing. School sports injury accident liability and preventive measures of [J] Chinese Journal of Wuhan Sports Institute, 2014, 01:53-56.

[4] Guo Xiujing. Study on the imputation principle of injury accident in school physical education [J].Educational science research, 2011, 11:32-35.

[5] Tan Xiaoyong, to the English, Jiang Xi.Research on the liability system of school sports injury accident [J].Journal of Tianjin University of Sport, 2011, 06:521-526.

[6] Luo Anyuan. Some suggestions on the liability and compensation for the injury accident of school physical education [J].Journal of Chongqing Education College, 2008, 06:123-124+131.

[7] Ye Ting. Legal liability of school sports injury accident [J]. Journal of Taizhou University, 2008, 06:53-57.

[8] Ye Ting. Legal liability of school sports injury accident [J]. Journal of Taizhou University, 2008, 06:53-57. 
[9] Zheng Bo. Comparative study on the ways of dealing with injury accident in school physical education in China and foreign countries [J]. Sports world (Academic Edition), 2012, 02:82-83.

[10]Jiang Yuanlei, Niu Yan. Study on the responsibility of the school sports injury accident [J]. Sports, 2012, 09:87-88+91. 